Jpn. J. Med. Mycol.

Vol. 25, 139-146, 1984

ISSN $0583-0516$

\title{
Hortaea, a New Genus to Accommodate Cladosporium werneckii
}

\author{
Kazuko Nishimura* and Makoto Miyaji \\ Department of Pathogenic Fungi, Research Institute for Chemobiodynamics, Chiba University \\ 1-8-1 Inohana, Chiba 280, Japan \\ [Received for Publication: October 21, 1983]
}

\begin{abstract}
A new genus, Hortaea Nishimura et Miyaji, is proposed to accommodate Cladosporium werneckii, the etiological agent of a superficial mycotic infection, tinea nigra, and Hortaea werneckii (Horta) Nishimura et Miyaji comb. nov. is provided.

The fungus is characterized by a unique sympodial conidiogenesis accompanying an annellidic one, which has been observed firstly using a scanning electron microscope as follows.

Conidiogenous loci arise from ampullaceous cells formed laterally or terminally on hyphae, lateral branches and projections on hyphae, or directly from the lateral walls of hyphae. These loci elongate and swell in accordance with the production of solitary, terminal conidia, and become thick cylindrical, obclavate or truncate rachises. Bud scars are found on the surface of the rachises, but denticles are absent. Round scars are observed in a few conidiogenous cells on the rachises, but most of the conidiogenous cells show remnants of scars shaped like sickles, half moons or scales. Regardless of the bud scar shapes, a spiral can be drawn on a rachis by tracing the centers of the scars. Namely, the conidiogenous cells are sympodulae because the bud scars are arranged on them sympodially. Such sympodial conidiogenesis is also found in most of the yeast-like conidiogenous cells.

Furthermore, there are a few conidiogenous cells with annellatons, which are irregular in comparison with those of $E$. dermatitidis or $E$. jeanselmei.

These results indicate that $H$. werneckii is definitely different from the other species of the genus Exophiala and other sympodial dematiaceous fungi.
\end{abstract}

In 1921, Horta1) described the causative agent of tinea nigra, a superficial mycotic infection occurring in South Asia, both American continents, Africa and Australia, as Cladosporium werneckii. Since then, opinions on that binominal have been divided and many synonyms were proposed by mycologists.

In 1970, von Arx ${ }^{2}$ described the fungus as Exophiala werneckii in his book without any comments. Thereafter, Gustafson et al. ${ }^{3)}$ and Cole ${ }^{4}$ found annellations on yeastlike cells of the fungus using a transmission and a scanning electron microscope, respectively. McGinnis ${ }^{5)}$ also reported that both the yeast-like and hyphal conidiogenous cells are annellides, and suggested that the conidiogenesis of the fungus is only annellidic.

On the other hand, Cole ${ }^{4}$ and Nishimura and Miyaji6) observed annellations on the conidiogenous cells of Exophiala salmonis, the type species of the genus Exophiala, using a scanning electron microscope. Nishimura and Miyaji ${ }^{7}$ ) $)$ observed E. dermatitidis, $E$. jeanselmei, and E. spinifera using a scanning electron microscope, and clarified the fact that their conidiogenous

*To whom correspondence should be addressed. cells are annellides.

From these data it seemed reasonable that Cladosporium werneckii was transferred to the genus Exophiala. In fact, mycologists such as Ajello9), Carmichael et al10), Cole ${ }^{4)}$, $\mathrm{McGinnis}^{5}$ ) and Rippon ${ }^{11}$ ) have agreed with von $\mathrm{Arx}^{2}$.

This time, we found a unique sympodial anamorph accompanying an annellidic one in "Exophiala werneckii" during our studies on the phylogenesis of black yeasts. The sympodial anamorph is definitely different from that of other sympodial genera such as Rhinocladiella and Ramichloridium. Therefore, we analyze the process of the conidiogenesis and propose a new genus, Hortaea, to accomodate $C$. werneckii.

\section{Materials and Methods}

A culture, $\mathrm{NCMH} \mathrm{75,} \mathrm{derived} \mathrm{from} \mathrm{the} \mathrm{neotype} \mathrm{of} E$. werneckii, which had been given to us by Dr. McGinnis (North Carolina Memorial Hospital, North Carolina, U.S.A.), was used in this study. Corn meal agar (Difco) and potato dextrose agar (Difco) were used as media. The culture was incubated on them at $27^{\circ} \mathrm{C}$ or room temperature which ranged from 5 to $20^{\circ} \mathrm{C}$. Colonies were cut into small blocks 14 to 34 days after inoculation and put in $2 \%$ 

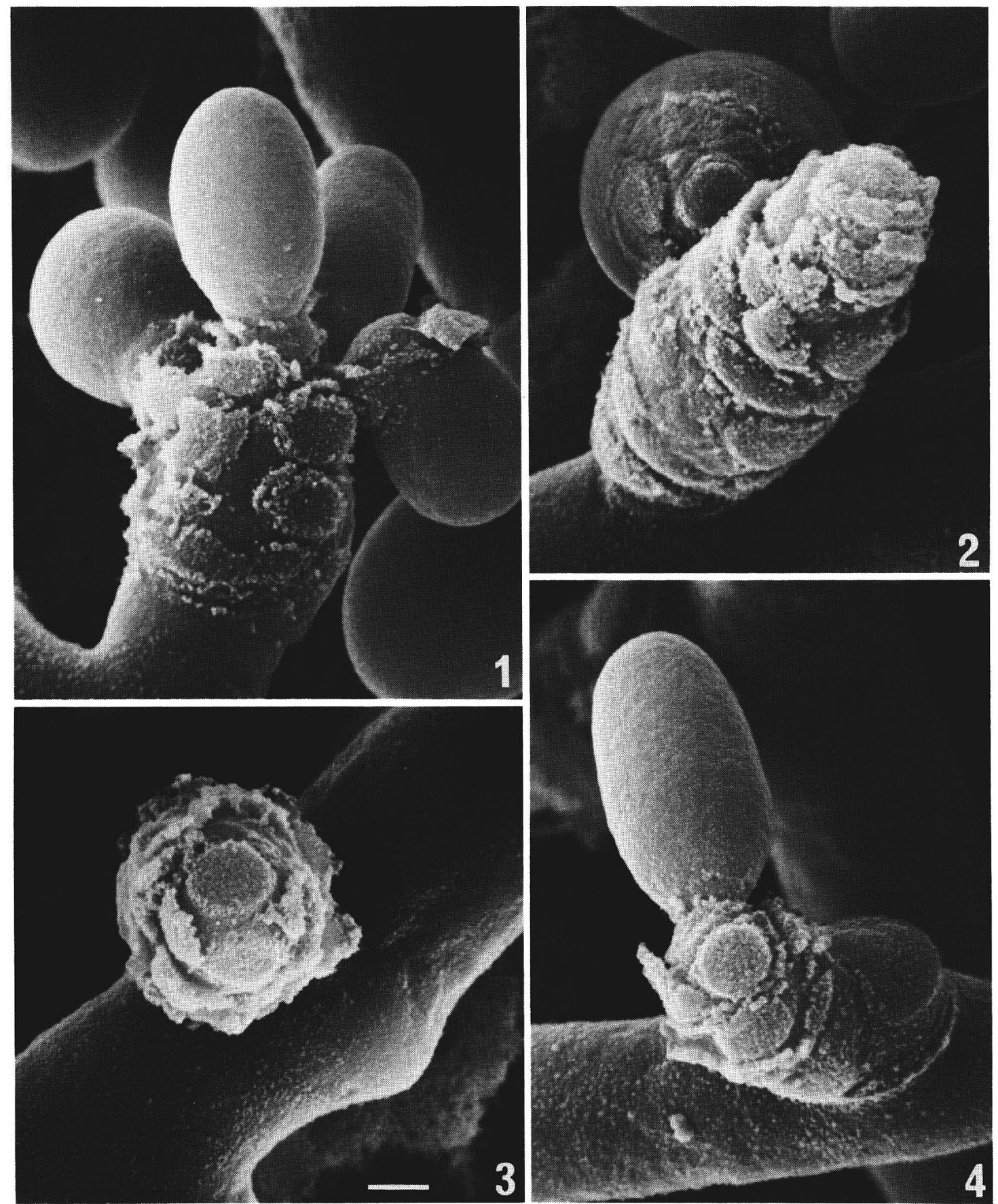

Figs. 1-4. Hortaea werneckii (NCMH 75). Scanning electron micrographs. Bar is $1 \mu \mathrm{m}$. 1. Rachis with round bud scars. Terminal conidia are acropetally produced. 2 . Rachis looking like a pine cone. 3 . Bird's eye view of a rachis. Two round bud scars are observed at the apex. 4 . Rachis with a round and lunate scars. 

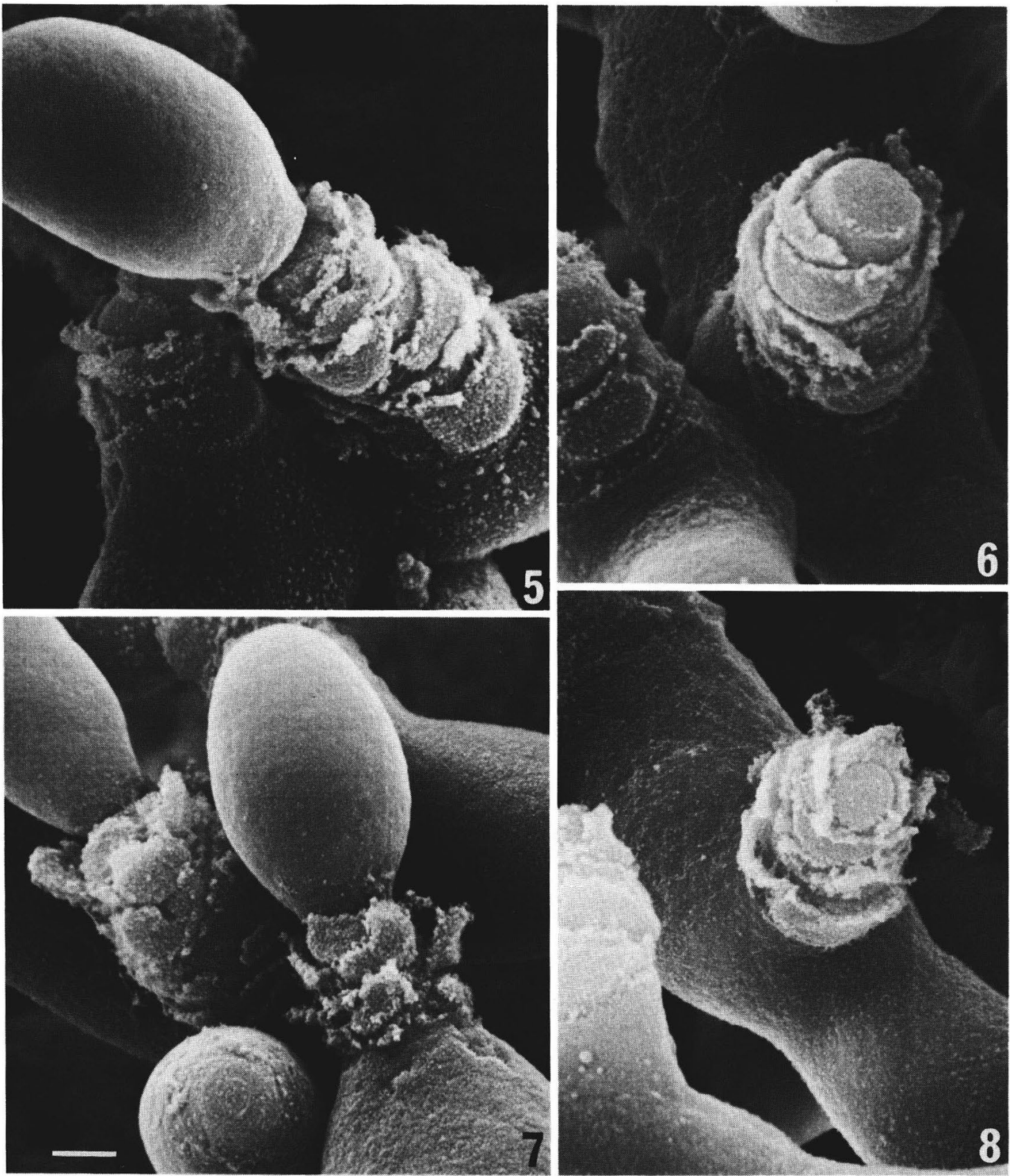

Figs. 5-8. Hortaea werneckii (NCMH 75). Scanning electron micrographs. Bar is $1 \mu \mathrm{m}$. 5 . Lunate bud scars alternate on a rachis. 6 . Bud scars are formed in a clockwise direction one after another at higher levels. 7. Bud scars looking like petals. 8. Rachis looking like a rose. A small round bud and falciform scars are observed. 

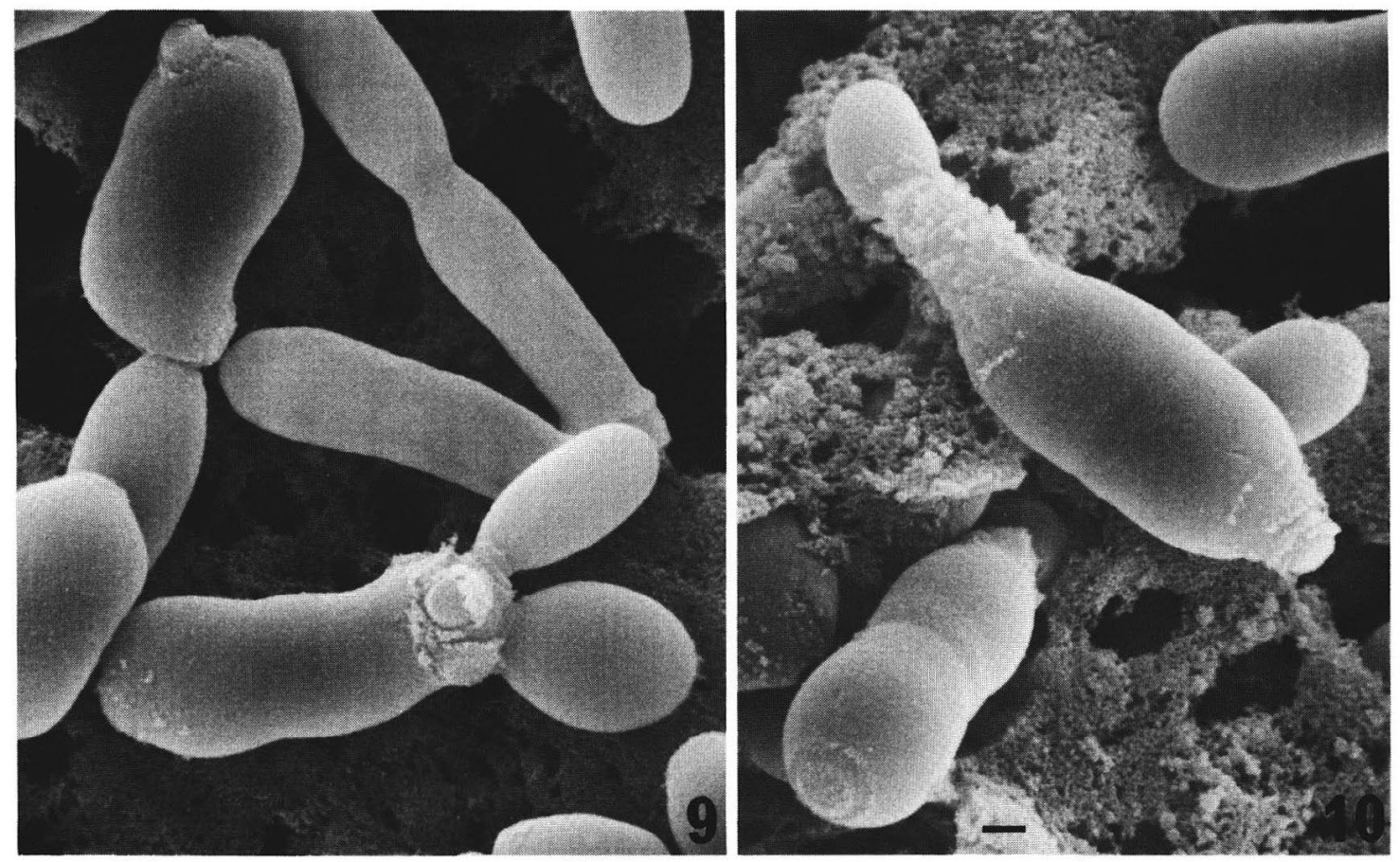

Figs. 9 and 10. Hortaea werneckii (NCMH 75), yeast form. Scanning electron micographs. Bar is $1 \mu \mathrm{m}$. 9. Yeastlike cells sympodially producing daughter cells. 10. Yeast-like cell with annellations.

glutaraldehyde. After having been fixed at $3^{\circ} \mathrm{C}$ for 24 hours and then $1 \%$ osmium tetroxide at $3^{\circ} \mathrm{C}$ for 17 hours, these blocks were dehydrated by a series of gradient alcohols, acetones, and by isoamyl acetate, then dried with a Critical Point Dryer HCP-1 (Hitachi), coated with gold palladium using an Ion Coater IB-3 (Eiko Engineering) Ltd.) and observed by a scanning electron microscope HFS-2 (Hitachi).

\section{Results}

In its mycelial form, conidiogenous loci occurred on ampullaceous cells formed laterally or terminally on hyphae, lateral branches and projections on hyphae, or directly from lateral walls of hyphae. These conidiogenous loci elongated and swelled in accordance with the production of solitary, terminal conidia, and became thick cylindrical, obclavate or truncate rachises which were $2.0-4.0$ (average 3.1) $\mu \mathrm{m}$ in diameter and 1.2-7.3 (average 4.3) $\mu \mathrm{m}$ in length. There were a few zigzag-shaped rachises (Fig. 5). Denticles were not detected on the surface of the rachises. Instead, various shapes of bud scars could be observed. In a few conidiogenous cells, round bud scars were arranged on the rachises in lengthwise rows (Fig. 1). Some rachises were covered with remnants of bud scars which looked like scales. These rachises had the appearance of pine cones or pineapples (Fig. 2).
In most of conidiogenous cells, remnants of bud scars shaped like sickles, half moons or scales were observed on the rachises. Each remnant was formed when a new conidium appeared by breaking through a part of a previously formed bud scar(s). In some cases, both round and lunate scars were observed on a rachis (Fig. 4). At the apices of rachises, one to two round scars were located, which were surrounded by remnants that looked like scales, half moons or sickles (Figs. 3, 6 and 8). In some cases, traces of the torn-off cell walls of the first conidium encircled the first bud scar and in other cases they were inconspicuous. On the other hand, petal-like appendages or short frills attached around the second and successive bud scars (Figs. 6-8). The appendages were parts of the preexisting bud scars, which were broken and lifted when the conidia were formed. The bud scars usually were $0.8-2.4 \mu \mathrm{m}$ in diameter.

Yeast-like cells produced daughter cells by unipolar or bipolar budding. In most of the yeast-like cells the conidiogenous apices were also covered with round bud scars or variously shaped remnants of bud scars (Fig. 9).

There were a few conidiogenous cells with annellations in both the mycelial and yeast forms (Fig. 10). Their number, in particular, was very low when cultured at room temperature. The annellations, which looked like short frills, were irregular in comparison with those of $E$. 
dermatitidis or $E$. jeanselmei. The annellated tips were cylindrical to tapering, 1.3-2.6 (average 1.9) $\mu \mathrm{m}$ in diameter, $0.3-6.2$ (average 2.3) $\mu \mathrm{m}$ in length, and consisted of one to nine annellations. Distances between the annellations were $0.22-1.36 \mu \mathrm{m}$.

\section{Discussion}

As reviewed by $\mathrm{McGinnis}^{5}$ ), the taxonomy of this dematiaceous yeast-like fungus has been confusing. Now, many mycologists have regarded this fungus as a member of the genus Exophiala and accepted the binominal, E. werneckii, even though Hermanides-Nijhof ${ }^{12)}$ considered it to be a later synonym of Sarcinomyces crustaceus and Borelli13) described it as Aureobasidium werneckii.

Gustafson et al. ${ }^{\text {) }}, \mathrm{Cole}^{4)}$ and McGinnis ${ }^{5}$ ) have indicated that $E$. werneckii has an annellidic anamorph. Cole $\left.{ }^{4}\right)$ demonstrated the annellidic anamorph in E. salmonis, the type species of the genus Exophiala, by scanning electron microscopy. Nishimura and Miyaji ${ }^{7,8)}$ observed the anamorphs of E. dermatitidis, E. jeanselmei, and E. spinifera by scanning electron microscopy and found the annellidic anamorph in these fungi, but never did find such anamorphs as the phialidic and sympodial anamorphs which had been reported by some mycologists ${ }^{14-16)}$. Furthermore, they demonstrated the annellidic anamorph in the culture derived from the type of $E$. salmonis ${ }^{6}$. Based on these results they have insisted that the anamorphs of the genus Exophiala are only annellidic.

On the other hand, in 1978, Cole ${ }^{4}$ ) demonstrated a scanning electron micrograph of $E$. werneckii, in which two conidia arose from a short lateral branch. According to his explanation, they occur in sympodial succession. However, his comment was so brief that it has not been clarified whether or not the fungus has a sympodial anamorph in addition to the annellidic one.

In this study, we clarified that the conidium ontogenesis of a culture derived from the neotype of $C$. werneckii consists of a combination of sympodial and annellidic anamorphs. In pleomorphic fungi, each anamorph often emerges independently. However, in the present fungus the two anamorphs (sympodial and annellidic ones) are closely related to each other. Additionally, its sympodial anamorph is unique as follows.

The conidiogenous cell as shown in Fig. 1 produces single, terminal conidia acropetally, at different levels. Even though denticles are not found on the surface of the conidiogenous cell and the rachis is not zigzag-shaped, the conidiogenous cell is a sympodula. However, there are a few such sympodial conidiogenous cells as shown in Fig. 1 in the present fungus. On the contrary, most of the conidiogenous cells have variously shaped bud scars on the surface as shown in Figs. 2-9. The arrangement of these bud scars varies from cell to cell. As far as we know, the mode of conidium formation as shown in these photographs has never been reported. We would like to discuss why such variously shaped scars remain on the conidiogenous cells and what the mode of conidium formation is.

As shown in Figs. 6 and 11A, bud scars are formed in a clockwise direction at the conidiogenous cell apex one after another at higher levels. Successive growing points emerge clockwise and spirally. In plants, where leaves or buds alternate on a stem, a spiral is drawn by tracing their insertions upwards. In botany, this spiral is defined as a "generic spiral." In our study, a spiral can also be drawn by tracing the centers of bud scars on a conidiogenous cell (Fig. 12A). We also refer to it as a "generic spiral" and designate the axis of rotation as the main axis. Additionally, we designate the angle of revolution between a bud scar and the next formed one as a divergence. In botany, a divergence is usually shown by one of the following progressions.

$1 / 2,1 / 3,2 / 5,3 / 8,5 / 13,8 / 21,13 / 34,21 / 55, \ldots \ldots$.

Namely, the denominator or numerator of a term is the sum of the two denominators or numerators just before the term, respectively.

It is well known that the divergence between a scale and the next one formed on a cone of the gymnosperms is shown by a $8 / 21,13 / 34$ or $21 / 55$ cycle. If the divergence of the present fungus is a $2 / 5$ cycle, bud scars are formed as shown in Fig. 11B. If the fifth conidium is the newest one, the fourth and fifth bud scars are observed at the conidiogenous cell apex as shown in Fig. 11C. This coincides with the conidiogeneous cell apex shown in Fig. 3. When the sixth conidium is produced just above the first conidium after two revolutions as shown in Fig. 12A, the round bud scars are arranged as shown in Fig. 1. If the pitch of a generic spiral is slightly smaller than the radius of the scar, new conidia occur by breaking through a part of the bud scars formed previously. As shown in Fig. 1, the upper parts of the bud scars on the left side are broken off. When the pitch becomes narrower, the conidiogenous cell is covered with lunate bud scars. When the divergence is a $3 / 8$ cycle and the pitch of a generic spiral is much smaller than the radius of the scar, the scaly bud scars overlap each other and the rachis becomes cone-like (Figs. 2 and 12B).

Next, we demonstrate conidiogenous cell apices as

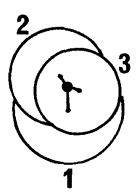

A

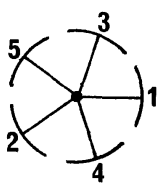

B

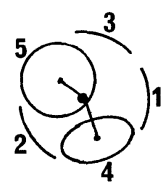

C
Fig. 11. Bud scars are labelled $1-5$ to indicate their order of formation. 


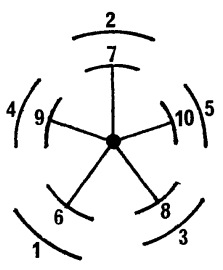

A1

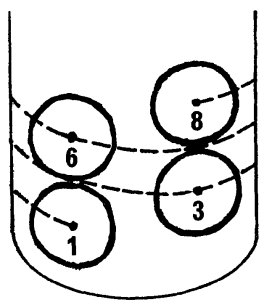

A2

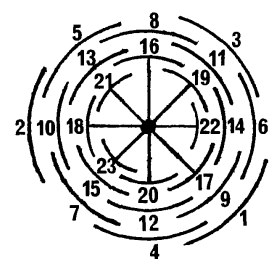

B1

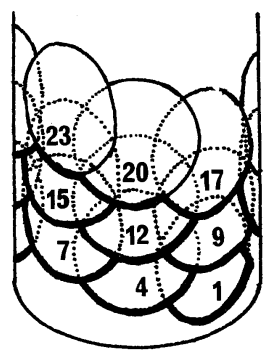

B2
Fig. 12. Bud scars are formed in the designated numerical order.

shown in Figs. 5-8, from which a conidium arises by breaking through the bud scar of the next older conidium. As shown in Fig. 6, when the radius of a generic spiral is small, a new conidium emerges by breaking through a part of the next older scar. As a result, lunate or falciform bud scars are spirally arranged around the main axis (Figs. 5 and 13). The rachises shown in Figs. $5-8$ seem to be formed by such a process. In fact, the diameters of the rachises shown in Figs. 5-8 are smaller than those shown in Figs. 1-4. When both the radius and pitch of a spiral are small, lunate or falciform bud scars overlap each other, and as a result, the rachis becomes shorter. When bud scars become gradually smaller towards the apices, the rachises become truncate or tapered as shown in Figs. 6 and 8 . When the radius of a generic spiral is almost equal to zero, the growing point extends along with the main axis, and as a result, annellations are formed (Fig. 10).

As mentioned above, the process of the conidium ontogenesis of the present fungus is explained quite well by our hypothesis. Even though various forms of rachises are observed, all of them are a homology of the conidiogenous cell shown in Fig. 1 and the mode of conidium formation is fundamentally sympodial. In the present fungus, the annellidic anamorph is also a homology of the sympodial anamorph.

According to Grove et al. ${ }^{17}$ ), the annelloconidia of $E$. dermatitidis are enteroblastically produced and released by abscission. Gustafson et al. ${ }^{\text {s) }}$, who studied the budding process of the yeast-like cells of $C$. werneckii with a transmission electron microscope, reported that increased electron opacity at the site of bud initiation, as reported by Grove et al., was not observed. Furthermore, they described that the collars (annellations) are formed not as a result of abscission but rather when successive daughter cells blastically emerge through the existing bud scar at the generative apices. According to them, the conidia of C. werneckii seem to be produced holoblastically and the annellations seem to be formed through processes different from those of $E$. dermatitidis.

According to $\mathrm{Mok}^{18)}$, E. werneckii decomposes casein but $E$. jeanselmei, E. spinifera and $E$. dermatitidis do not. In our study, the present fungus hydrolyzes skim milk but six species of the genus Exophiala do not (unpublished data). Judging from these results, the present fungus is different from the species of the genus Exophiala.

According to Pechak and Crang ${ }^{19}$ ), Aureobasidium pullulans produces conidia enteroblastically. It also differs

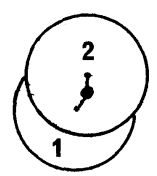

A1

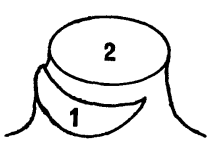

B1

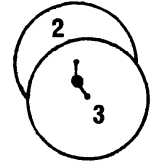

A2

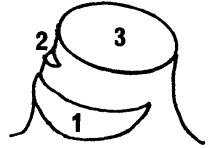

B2

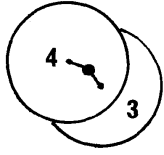

A3

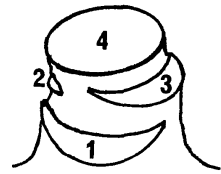

B3

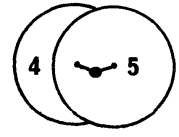

A4

Fig. 13. Bud scars are labelled $1-5$ to indicate their order of formation. 
from the present fungus in conidiogenesis.

In 1977 , Hermanides-Nijhof ${ }^{12}$ ) stated that E. werneckii is a later synonym of Sarcinomyces crustaceus Lindner. However, her opinion has not been accepted by McGinnis $^{5}$ and Carmichael et al. ${ }^{10}$ ). Furthermore, the reproduction of $S$. crustaceus as indicated by Sigler et al. ${ }^{20)}$, using a scanning electron microscope, is definitely different from that of the present fungus. Additionally, the conidiogenesis is definitely different from the descriptions and illustrations of Lindner which were cited by Sigler et al. De Hoog and Rubio's) found that the S. crustaceus strain used by Sigler et al. has both blastic and sarcinic (meristematic) conidiogeneses. They did not describe any sympodial conidiogenesis in the strain of S. crustaceus. Furthermore, the sympodial conidiogenesis of the present fungus is definitely different from that of any other species of sympodial genera.

The type specimen was prepared from the culture derived from the neotype of $E$. werneckii by McGinnis and has been preserved in New York Botanical Garden. We did not observe the type specimen because the present study was performed using a scanning electron microscope. We prepared slide culture preparations of the present fungus and reconfirmed that many conidiogenous cells of the fungus look like annellides under a light microscope, even though they are sympodulae. We know that the fungus should be compared with the type specimen, when a new taxon is proposed. However, as mentioned above, the new genus Hortaea is proposed on the basis of the findings not by a light microscope but by a scanning electron microscope.

In 1982, von Arx et al. ${ }^{22)}$ observed a sympodial anamorph with an annellidic one in Taphrina deformans. However, they did not give detailed explanations of the sympodial anamorph and of the relationship between the two anamorphs.

The conidium ontogenesis of $H$. werneckii may reveal an intermediate form between the annellidic and sympodial conidiogeneses. We suppose that the annellidic conidiogenesis might have been differentiated from the sympodial one in the present fungus. Studies on conidium ontogenesis in pleomorphic fungi will be of importance to clarify the conidium morphogenesis of the Fungi Imperfecti.

Based on this observation, we would like to propose a new genus, Hortaea, to accommodate C. werneckii.

\section{Description}

Hortaea Nishimura et Miyaji, gen. nov.

Etymology: In memory of Dr. Parreiras Horta, Professor of Dermatology.

Mycelium cylindricum vel toruloideum, pallide brunneum vel atrobrunneum. Conidiophora semi-macronemata vel micronemata, ramosa vel simplicia, septata, pallide brunnea vel nigra. Cellulae conidiogenae (sympodulae) incorporatae vel terminales, cylindricae vel ampulliformes, pallide brunneae vel nigrae; rachides (partes fertiles) truncatae, cylindricae vel obclavatae, cum cicatricibus gemmarum in ordinem spiralem; cicatrices gemmarum rotundae, lunatae, falcatae vel squamosae; denticuli absentes. Cellulae conidiogenae (annellides) raro producentes. Conidia solitaria, acropleurogena vel acrogena, uni- vel bi-cellularia, ellipsoidea vel cylindrica, pallide brunnea vel nigra, interdum aggregata in uvas.

Cellulae fermentoidea uni- vel bi-cellulares, ellipsoideae vel cylindricae, pallide brunneae vel nigrae, cum cicatricibus gemmarum sympodialiter ordinatis vel cum annellis, per germinationem unipolares vel bipolares deinceps conidia producentes.

Teleomorphosis ignota.

Species typica: Hortaea werneckii (Horta) Nishimura et Miyaji.

Mycelium cylindrical to toruloid, pale to dark brown. Conidiophores semi-macronematous to micronematous, branched or unbranched, septate, pale brown to black. Conidiogenous cells (sympodulae) incorporated or terminal, cylindrical or ampullaceous, pale brown to black; rachises (fertile parts) of sympodulae truncate, cylindrical or obclavate with bud scars in spiral arrangement; bud scars round, lunate, falcate or scaly; denticles absent. Conidiogenous cells (annellides) rarely produced. Conidia solitary, acropleurogenous or acrogenous, one- to twocelled, ellipsoidal to cylindrical, pale brown to black, sometimes aggregated in clusters.

Yeast-like cells one- to two-celled, ellipsoidal to cylindrical, pale brown to black, with bud scars sympodially arranged or with annellations, producing conida by unipolar or bipolar budding.

Teleomorph unknown.

Hortaea werneckii (Horta) Nishimura et Miyaji, comb. nov. (Figs. 1-10)

Basionym: Cladosporium werneckii Horta, Rev. Med. Cir. Braz. 29: 269, 1921.

इDematium werneckii (Horta) Dodge, Medical Mycology, Mosby, St. Louis, p. 677, 1935.

$\equiv$ Pullularia werneckii (Horta) de Vries, Contribution to the Knowledge of the genus Cladosporium Link ex Fr., Hollandia, Baarn, p. 101, 1952.

$\equiv$ Exophiala werneckii (Horta) von Arx, The Genera of Fungi Sporulating in Pure Culture, J. Cramer, Lehre, p. 180, 1970.

=Cryptococcus metaniger Castell., Arch. Dermatol. Syphilol. 16: 402, 1927.

三Cladosporium metanigrum (Castell.) Ferrari, Atti. Ist. Bot. Univ. Lab. Crittog. Pavia, Ser. 4, 3: 183, 1932.

=Pullularia fermentans Wynne et Gott var. castellanii 
Wynne et Gott, J. Gen. Microbiol. 14: 518, 1956 (name change).

$\equiv$ Pullularia fermentans Wynne et Gott var. leaoi Wynne et Gott, ibid. 14: 517, 1956.

Colonies at first smooth, shiny, moist, becoming dry or moist, thin felt with growth of superficial and immersed hyphae. Colonies on Sabouraud's dextrose agar, potato dextrose agar or corn meal agar at $27^{\circ} \mathrm{C}$ on the 14 th day, attaining $18-20 \mathrm{~mm}$ in diameter, greenish buff, brown to greenish black. Conidiogenous cells (sympodulae), incorporated or terminal, cylindrical or ampullaceous, pale brown to black; rachises of sympodulae 1.2-7.3 (av. 4.3) $\mu \mathrm{m}$ in length, 2.0-4.0 (av. 3.1) $\mu \mathrm{m}$ in diameter, truncate, cylindrical or obclavate with bud scars $0.8-2.4 \mu \mathrm{m}$ in diameter, round, lunate, falcate or scaly, encircled with or without frills or petal-like appendages; denticles not produced. Conidiogenous cells (annellides) rarely produced, $0.3-6.2$ (av. 2.3) $\times 1.3-2.6$ (av. 1.9) $\mu \mathrm{m}$, truncate or cylindrical, with 1-9 annellations. Conidia one- to twocelled, ellipsoidal to cylindrical, pale brown to black, 3.88.1 (av. 6.0) $\times 2.3-3.9$ (av. 3.1) $\mu \mathrm{m}$.

Yeast-like cells one- to two-celled, ellipsoidal to cylindrical, pale brown to black, 6.8-13.3 (av. 9.5) × 3.0-4.6 (av. 4.0) $\mu \mathrm{m}$ including condiogenous apices, producing sympodio- or annelloconidia by unipolar or bipolar budding.

Specimen examined: NCMH 75 (=CBS 107.67, ATCC 36317), isolated from a patient with tinea nigra in Portugal, sent by M.R. McGinnis.

\section{Acknowledgments}

We are most indebted to Dr. McGinnis for providing the culture and thank Dr. Hanlin for critically reviewing the manuscript.

\section{References}

1) Horta, P.: Sobre um caso de tinha preta e um novo cogumelo (Cladosporium werneckii). Revista Medico Cirurgica do Brazil, 29: 267-274, 1921.

2) von Arx, J.A.: The Genera of Fungi Sporulating in Pure Culture 1st ed. J. Cramer, Lehre. p. 180, 1970.

3) Gustafson, R.A., Hardcastle, R.V. and Szaniszlo, P.J.: Budding in the dimorphic fungus Cladosporium werneckii. Mycologia, 67: 942-951, 1975.

4) Cole, G.T.: Conidiogenesis in the black yeasts. In The Black and White Yeasts, Pan American Health Organization, Sci. Publ. No. 356, Washington D.C., p. 66-78, 1978.

5) McGinnis, M.R.: Taxonomy of Exophiala werneckii and its relationship to Microsporum mansonii. Sabouraudia, 17: 145-154, 1979.

6) Nishimura, K.: Phylogenesis of pathogenic black yeasts. Abstracts of The 3rd International Mycological Congress. p. 212, 28th Aug.-3rd Sept., Tokyo, 1983.

7) Nishimura, K. and Miyaji, M.: Studies on a saprophyte of $E x$ ophiala dermatitidis isolated from a humidifier. Mycopathologia, 77: 173-181, 1982.

8) Nishimura, K. and Miyaji, M.: Studies on the phylogenesis of pathogenic black yeasts. Mycopathologia, 81: 135-144, 1983.

9) Ajello, L.: The black yeasts as disease agents. In The Black and White Yeasts, Pan American Health Organization, Sci. Publ. No. 356, Washington D.C., p. 9-16, 1978.

10) Carmichael, J.W., Kendrick, W.B., Conners, I.L. and Sigler, L.: Genera of Hyphomycetes. The University of Alberta Press, Edmonton, p. 90, 1980.

11) Rippon, J.W.: Medical Mycology, the Pathogenic Fungi and the Pathogenic Actinomycetes, 2nd ed. W.B. Saunders Company, Philadelphia, p. 145-148, 1982.

12) Hermanides-Nijhof, E.J.: Aureobasidium and Allied Genera. CBS Studies in Mycology, 15: 141-177, 1977.

13) Borelli, D.: Aureobasidium werneckii: Acervuli, sporodochia and pycnidia, In The Black and White Yeasts, Pan American Health Organization, Sci. Publ. No. 356 Washington D.C., p. 79-90, 1978.

14) de Hoog, G.S.: Rhinocladiella and Allied Genera. CBS Studies in Mycology, 15: 1-140, 1977.

15) McGinnis, M.R.: Wangiella, a new genus to accommodate Hormiscium dermatitidis. Mycotaxon, 5: 353-363, 1977.

16) Wang, C.J.K.: Pleomorphic Fungi Imperfecti. In The Whole Fungus. Vol. 1. (Kendrick, B. ed.), The University of Waterloo Press, Waterloo, p. 81-91, 1979.

17) Grove, S.N., Oujezdsky, K.B. and Szaniszlo, P.J.: Budding in the dimorphic fungus Phialophora dermatitidis. J. Bacteriol., 115: 323-329, 1973.

18) Mok, W.Y.: Nature and identification of Exophiala werneckii. J. Clin. Microbiol., 16: 976-978, 1982.

19) Pechak, D.G. and Crang, R.E.: An analysis of Aureobasidium pullulans, developmental stages by means of scanning electron microscopy. Mycologia, 69: 783-792, 1977.

20) Sigler, L., Tsuneda, A. and Carmichael, J.W.: Phaeotheca and Phaeosclera, two new genera of dematiaceous hyphomycetes and a redescription of Sarcinomyces Lindner. Mycotaxon, 12: 449-467, 1981.

21) de Hoog, G.S. and Rubio, C.: A new dematiaceous fungus from human skin. Sabouraudia, 20: 15-20, 1982.

22) von Arx, J.A., van der Walt, J.P. and Liebenberg, N.V.D.M.: The classification of Taphrina and other fungi with yeast-like cultural states. Mycologia, 74: 285-296, 1982. 